\title{
Determinants of the Financial Literacy: Case Study on Career Woman in Indonesia
}

\author{
Novia Dewanty ${ }^{1}$, Yuyun Isbanah ${ }^{2}$
}

\begin{abstract}
Financial literacy is one of the relevant facts in improving the economy. The purpose of this study was to examine the influence of demographic factors (i.e., marital status, education level, income, and age) and financial socialization agent on financial literacy. Using online and offline questionnaire survey from 100 respondents in Surabaya, East Java, and the study revealed that education level, personal income, and financial socialization agent, give the positive effect, while the marital status and age does not affect financial literacy. This result implies that the government can focus on educating the development and improvement of financial literacy for the society. It is believed to be a step forward in practicing financial planning from an early age to solve problems with financial management using financial knowledge, financial attitude, and financial behavior.
\end{abstract}

Keywords: demographics, financial socialization agent, financial literacy

\begin{abstract}
Abstrak. Literasi keuangan merupakan salah satu faktor yang relevan untuk meningkatkan perekonomian. Tujuan penelitian ini untuk menguji pengaruh faktor demografi (yaitu: status perkawinan, tingkat pendidikan, pendapatan, dan usia) dan financial socialization agent terhadap literasi keuangan. Menggunakan kuisioner terhadap 100 responden di Surabaya Jawa Timur, penelitian ini menunjukkan bahwa tingkat pendidikan, pendapatan, dan sosialisasi oleh agen berpengaruh positif terhadap literasi keuangan, sedangkan status perkawinan dan usia tidak berpengaruh terhadap literasi keuangan. Hasil ini mengimplikasikan bahwa, pemerintah dapat fokus untuk mendidik pengembangan dan peningkatan melek finansial bagi masyarakat. Hal ini diyakini sebagai langkah tepat dalam mempraktekkan perencanaan keuangan sejak dini untuk menyelesaikan masalah dengan manajemen keuangan melalui pengetahuan keuangan, sikap terhadap keuangan, dan perilaku keuangan.
\end{abstract}

Kata kunci: demografi; financial socialization agent; literasi keuangan

\section{How to Cite:}

Dewanty, N., \& Isbanah, Y. (2018). Determinant of The Financial Literarcy: Case Study on Career Woman in Indonesia. Etikonomi: Jurnal Ekonomi. Vol. 17 (2): 285 - 296. doi: http//dx.doi.org/10.15408/etk.v17i2.6681. 


\section{Introduction}

The financial understanding of all levels of society supports the acceleration of an economy's country. Financial literacy is one of the relevant facts in improving the economy. The economy of a country can boost growth by improving the people's financial situation; increasing financial literacy will help the financial situation of the society be better for making financial decisions (Agarwalla et al., 2013). Financial literacy is the way individuals or communities manage personal financial resources with their knowledge and implementation (Warsono, 2010).

Organization for Economic Co-operation and Development (OECD) define the financial literacy adopted from several studies that combination of knowledge skills, attitude and behavior the dimension for making financial decisions and ultimately achieve right personal finance (OECD, 2016). The definition shows the different dimensions and possible measurement of the associated financial literacy of financial knowledge, financial attitude, and financial behavior.

Financial knowledge is crucial in the life as a useful tool for making financial decisions, but from research in various countries still show relatively low financial knowledge society (Orton, 2007). Based on the results of Household Balance Survey Bank of Indonesia in 2011 shows that the use of savings accounts by households was only $43.75 \%$, and only $19.58 \%$ was the short number of households debts in the bank. This fact is due to a lack of awareness of the needs of individuals or communities that should have an understanding of the benefits and risks of financial products and services to improve the public welfare of selected products.

The National Strategy of Financial Literacy 2014, show that the level of financial literacy of women in Indonesia only $18.84 \%$. This level is still relatively low when compared with men who are in the $24.8 \%$. The woman has $52.9 \%$ micro business and giving the contribution to economic growth (International Finance Corporation Survey, 2016). The financial performance of female business owners is better than male. The influence of business orientation of women on the financial performance of $83.5 \%$ while men only $39.7 \%$ (Kumalaningrum, 2010). Individual fund saving decisions influenced by demographic factors such as age, gender, marital status, education level, number of children, and work experience (Mahdzan and Tabiani, 2013).

Brown and Graf, (2013) estimate the gender effect separately with the marital status (single or another status). Supports the statement that the increasing level of a student's education will affect the level of financial literacy and behavior in credit taking (Agnew and Harrison, 2015). The level of financial literacy correlates with income levels (Alwee and Salleh, 2015). Age has an influential role in one of the factors of financial literacy. Hogarth and Hilgert (2002) underline the middle age group tends to have high financial literacy compared to young or old age.

The results of Agarwalla et al., (2013) stated that the status of marriage negatively affect the financial literacy that is in the financial knowledge of beginner workers in India. While 
in the financial attitude and behavior marital status has no effect. (Alwee and Salleh, 2015) reinforces the assertion that marital status in financial literacy has no effect in comparing the literacy of public welfare finances in Brunei. (Ansong and Gyensare, 2012) found no correlation or influence of education with literacy. (Amaliyah and Witiastuti, 2015) stated that the income level above IDR 2,100,000 and below IDR 2,100,000 did not affect the level of financial literacy. Agnew and Harrison (2015) in his research on student attitudes in credit decision making states there is a negative influence between ages with the level of financial literacy. Ansong and Gyensare (2012) who reject the existence of financial socialization agent significance to financial literacy.

The Financial Socialization Agent (FSA) is one of the key contributors to the provision and advice of financial information (Brown et al., 2008). Financial knowledge is not only derived from formal education but also interactions with socialization agents such as family, peers, and media (Hilgert et al, 2003). Sohn et al (2012) state that financial socialization agent has a positive impact on the level of student's financial literacy in South Korea.

Lack of knowledge and understanding of literacy will affect directly against the wellbeing of the individual. Due to the low financial literacy to make individuals experiencing a variety of problems that engaged with personal finances such as savings, investments, or old plans, credit and so on and awareness in financial management with good is still very lacking in Surabaya. High rates of Surabaya's economy are not in line with the understanding and knowledge of the financial literacy community in Surabaya. The industrial sector, trade, real estate, and services in Surabaya showed growth of 51.78\% whereas the information and communication sector as well as financial services and insurance only amounting to $5.33 \%$ and $5.46 \%$. It proves that public access to financial institutions is still lacking. Proven by research done by Andrew and Linawati (2014) knowledge and behavioral finance to private employees in Surabaya demonstrate the selected main investment savings of 31\%. It does not describe how an individual financial behavior when faced with a financial decision making (Sarah, 2009). The most significant advantage of financial literacy is to reduce the financial problems of employees and encourage them to be responsible for their financing and help improve efficiency in the Organization (Vitt et al., 2000). Employees who work in financial environments tend to have the knowledge and sound financial behavior due to experience working with the knowledge in making employees more efficiently manage his finances well everyday life or in planning the future of the children and or savings for old age.

This study aims to analyze the influence of marital status, education level, income, and age and financial socialization agent on financial literacy that divided into three dimensions. Those are financial knowledge, financial attitude, and financial behavior.

\section{Method}

This study uses a type of causality research. Causality research is a type of research used to obtain evidence of causality (Malhotra, 2005). The variables used are exogenous variables 
of financial literacy, and endogenous variables consisting of demographic variables of marital status, education, income, age, and financial socialization agent.

The number of samples in this studies as many as 100 respondents who are women workers financial sector. The sample of this study must occupy several requirements, among others: First, the women over 20 years old. Second, the respondent that is working in a company of Financial Sector (Bank / Non-Bank) in Surabaya, Indonesia.

Data collected through online and offline questionnaires. The measurement scale is Guttmann and Likert scale. Data analysis in this research uses Partial Least Square 3.0 (Smart-PLS). The Smart-PLS is employed to evaluate the survey questionnaire data because it can deliver latent variable scores, avoid small sample size problems, and estimate reflective and formative models that have many latent and manifest variables (Henseler et al. 2009). The procedure of analyzing data is, first, validity and reliability of the instrument were determined using confirmatory factor analysis. Second, the structural model was assessed using standardized betas $(\beta)$ and $t$ statistics (two tail testing: $t>1.96$ ). Third, the value of $\mathrm{R}^{2}$ utilized as a criterion of the overall predictive strength of the model (i.e., 0.19 (weak), 0.33 (moderate) and 0.67 (substantial) (Henseler et al., 2009). Finally, the value of Q2 was used as a measure of the model's predictive relevance (i.e., 0.02 (weak), 0.15 (medium) and 0.35 (large) (Hair et al., 2014).

\section{Result and Discussion}

The respondents in this research are 100\% female with 56\% (56 respondents) bank worker and 44\% (44 respondents) non-bank worker (insurance, cooperative and leasing). The result of respondent characteristic in terms of marital status with 77\% (77 respondents) is single and 23\% (23 respondents) is married. Based on high school graduates education level 20\% (20 respondent), Diploma/Bachelor 78\% (78 respondent) and postgraduate 2\% (2 respondent). Personal income of respondents with nominal below IDR 3,025,000 is 11\% (11 respondent), IDR 3,025,000 - IDR 5,000,000 for 75\% (75 respondent) and above IDR $5,000,000$ for $14 \%$ (14 respondent).

The validity of the questionnaire measured from convergent validity with loading factor above 0.70 . Reliability measured through the value of composite reliability and Cronbach's alpha above 0.70 (Ghozali, 2014). Testing validity and reliability using smart pls 3.0. Test of validity shows that there is an indicator of financial literacy that has outer loading less than 0.7 (See Table 1), so it will drop from the model and reestimated. 
Table 1. Convergent Validity

\begin{tabular}{|c|c|c|}
\hline Variable & Outer Loading & Status \\
\hline Marital Status & 1,00 & Valid \\
\hline Education Levels & 1,00 & Valid \\
\hline Personal Income & 1,00 & Valid \\
\hline Age & 1,00 & Valid \\
\hline \multicolumn{3}{|l|}{ Financial Socialization Agent } \\
\hline - Family & 0,975 & Valid \\
\hline - $\quad$ Peers & 0,925 & Valid \\
\hline - Media & 0,980 & Valid \\
\hline Financial Knowledge & 0,940 & Valid \\
\hline \multicolumn{3}{|l|}{ Financial Attitude } \\
\hline Attitude toward money for the short- term & 0,857 & Valid \\
\hline Attitude toward money for the long-term & 0,802 & Valid \\
\hline Planning for future & 0,790 & Valid \\
\hline \multicolumn{3}{|l|}{ Financial Behavior } \\
\hline Management Budgeting & 0,988 & Valid \\
\hline Priority Budgeting & 0,957 & Valid \\
\hline Loan identify & 0,903 & Valid \\
\hline Loan for needs & 0,920 & Valid \\
\hline Choosing product & 0,894 & Valid \\
\hline Bills payment & 0,884 & Valid \\
\hline Financial supervision & 0,970 & Valid \\
\hline Goal setting & 0,965 & Valid \\
\hline Active savings & 0,468 & Not Valid \\
\hline
\end{tabular}

The results of re-estimated can see in Figure 1. Figure 1 shows the outer loading results with the loading factor occupying the convergent validity and corresponding to the goodness-of-fit.

Figure 1. Re-estimate Path Diagram

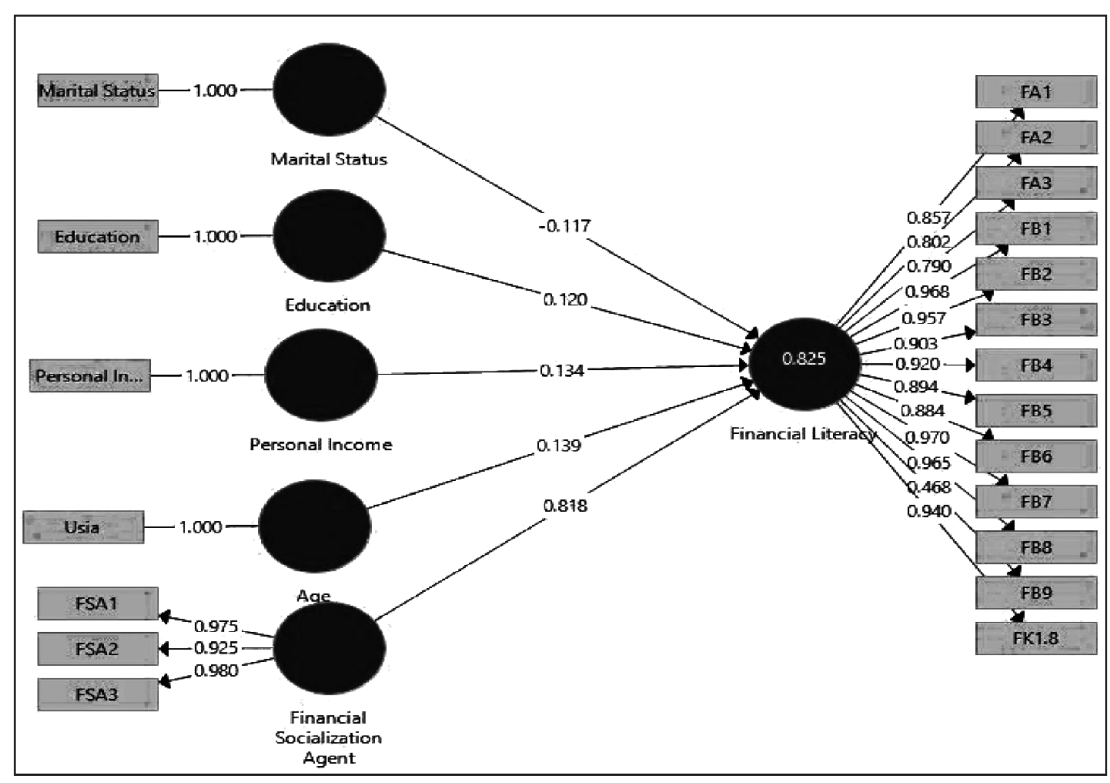


Table 2 shows that the model occupies the composite reliability and Cronbach's alpha because the variable value is above 0.70 and occupy the goodness-of-fit criteria. After the test of validity and reliability then the model can be analyzed. PLS analysis using bootstrapping resampling. Value of t-statistic $5 \% \geq 1.96$ or $p$-value $\leq 0.05$ said that the variable affected.

Table 2. Reliability Test

\begin{tabular}{lccc}
\hline & $\begin{array}{c}\text { Composite } \\
\text { Reliability }\end{array}$ & Cronchbacs Alpha & $\begin{array}{c}\text { Status } \\
\text { (Reliable if }>0,70)\end{array}$ \\
\hline Age & 1.000 & 1.000 & Reliable \\
Education & 1.000 & 1.000 & Reliable \\
Financial Literacy & 0.982 & 0.980 & Reliable \\
Financial Socialization Agent & 0.973 & 0.957 & Reliable \\
Marital Status & 1.000 & 1.000 & Reliable \\
Personal Income & 1.000 & 1.000 & Reliable \\
\hline
\end{tabular}

Table 3 shows the marital status does not affect financial literacy because it has $\mathrm{t}$-statistics of $1.884 \leq \mathrm{t}$ table $1.96(5 \%)$. The level of education has a positive parameter coefficient of 0.12 and t-statistics of $2.134 \geq 1.96(5 \%)$, so it concluded that the level of education has a positive effect on financial literacy. Personal income has a parameter coefficient of 0.131 and t-statistics of $2.276 \geq 1.96(5 \%)$, so it concluded that income has a positive effect on financial literacy. Age does not affect financial literacy because it has t-statistics of $1.657 \leq 1.96(5 \%)$. Financial socialization agent has a parameter coefficient of 0.818 and t-statistics of $10.342 \geq 1.96(5 \%)$, so it can conclude that financial socialization agent has a positive effect on financial literacy.

Table 3. Path Coefficients

\begin{tabular}{lccc}
\hline & Original Sample (O) & t- Statistic & P Value \\
\hline Marital Status $\rightarrow$ financial literacy & -0.113 & 1.884 & 0.060 \\
Education $\rightarrow$ financial literacy & 0.120 & 2.134 & 0.033 \\
Personal Income financial literacy & 0.131 & 2.276 & 0.023 \\
Age $\rightarrow$ financial literacy & 0.137 & 1.657 & 0.098 \\
Financial Socialization Agent $\rightarrow$ financial literacy & 0.818 & 10.342 & 0.000 \\
R Square Adjusted & 0.815 & 12.345 & 0.000 \\
\hline
\end{tabular}

Tests on the structural model done by viewing and R-Square Adjusted of 0.815 that can interpret that the variable of financial literacy construct can be explained by demographic 
and financial socialization agent variable equal to $81,5 \%$ while $18,5 \%$ is explained by other variables not examined.

Marital status did not affect financial literacy and seen from the parameter coefficient indicates the direction of the negative sign. Where should the respondents who have married status have a better financial position because more residual income than unmarried and the percentage of income is much higher than the expenditure (Sundjaja et al, 2015). Alwee and Salleh (2015) conducted in Brunei by conducting study on the level of financial literacy of prosperous society states that the status marital does not significantly affect the comparison of financial literacy as seen from the expenditure for the married community $75 \%$ deficit in finance, while only $2 \%$ The deficit experienced by the single.

The financial position of respondents can cause the occurrence of insignificant influence in this study with married status get higher income because with marital status is a combination of husband and wife income, so the difference should be higher acceptance than single employees should. However, married employees will be more in the use of money for the needs, because it can make the expenditure of employees married status higher than the income received (Sundjaja et al, 2015).

Another reason is that the majority of respondents $77 \%$ are single or unmarried who financially could be still living with parents needs fulfilled family. Single women can manage their finances. Agarwalla et al (2013) stated that women tend to be better at managing and making financial decisions. Therefore, that single status women have full rights in financial management compared with married status because financial management, which is done together with the husband so that there are different responsibilities in the household in making the financial decision (Brown and Graf, 2013).

The level of education affects the financial literacy and has a positive impact. The higher the education levels, the higher of financial literacy. A higher level of education will make it easier for someone to absorb information and implement it in everyday behavior and lifestyle. The level of formal education forms a value for someone especially in accepting new things. Agnew and Harrison (2015) support that a higher level of education will affect the level of financial literacy and behavior in credit taking and there is a positive impact between the level of education and financial literacy. Because the education level is essential to predict the level of financial literacy (Margaretha and Sari, 2015).

Employees working in the financial sector tend to have good financial literacy because with the knowledge and experience during the work to make employees more efficiently manage and make personal financial decisions to overcome the problems in finance either short or long term. Income or personal income affects a positive effect on financial literacy. This result shows that the higher the income, the higher the level of financial literacy. The results of this study following previous research from Agarwalla et al (2013) states that the level of income of teenage workers has a positive effect with financial literacy in India, as measured from the level of understanding of financial problems. Margaretha and Sari (2015) found that there was a positive effect of income on financial literacy on credit card users. The higher the individual income, the higher the 
financial literacy. Scheresberg (2013) state that financial literacy increases with income increases.

Age does not affect financial literacy. These findings are consistent with Muat et al., (2014) suggesting that there is no effect of age influence on financial literacy in private loan decision-making. Lecturers who teach at UIN Suska Riau because majority respondents are younger $25-35$ years $52.46 \%$ of respondents total. Age size has no impact on financial literacy so that no matter how old a person can not measure his financial literacy. The incidence of insignificant influence in this study may be due to a large number of young respondents, i.e., 20-30 years of $82 \%$, so less can see if the age difference is increasing (old) shows the financial literacy may be due to lack of financial experience or financial problems experienced. Other causes of age do not affect due to financial mismanagement that should be early on, which is difficult to overcome in old age. Awareness of financial literacy is critical to do at a young age because of the inverse relationship between age and income level. Where age is increasing, individual productivity is declining, but the cost of living continues to rise, and the emergence of many unexpected problems as age progresses to old age, such as health costs and inflation (Sundjaja et al., 2015). Hogarth and Hilgert, (2002) underline that middle age groups tend to have high financial literacy compared to young or old age groups. However, this research is different with Mouna and Anis (2017) and Garg and Singh (2018). They found that the financial literacy was affected by age, education level, and the annual income.

Sardiana (2016) stated that the financial literacy could affect the preference and usage of the services. Knowledge is one of the factors that had an impact on the preferences. Financial socialization agent affects the financial literacy and shows a positive effect on the financial literacy (Yildirim et al., 2017). Sohn et al. (2012) state that financial socialization agent affects the financial literacy of adolescents in Korea. The media became an agent of interest to teenagers while in Indonesia $78 \%$ of financial, social agents came from families. The family has become the most fundamental agent to provide financial information, especially for his children. Potrich et al. (2015) confirm the urgency and need for devising effective actions to minimize the issue of financial literacy.

The principal applied financial things are the attitude in saving and attitude in taking credit. The family considered the most reliable source because it becomes the closest environment. Peers and media also received considerable attention for respondents where $72.4 \%$ of respondents also chose peers and media as financial, social agents. The role of peers or colleagues who have much financial information and supported by experience in the workplace so that respondents exchange information, it was seen from the respondents that came from the financial sector. Media is also a financial agent selected as a source of information for financial planning and relate to increasing financial satisfaction (financial satisfaction). The media can provide information directly because it is easy to access financial information from the Internet. Even though many media such as Television, Newspapers, Radio or software that launched several financial services in helping people to be able to choose financial products well. Financial socialization agents help to improve financial literacy towards the better. Rasoaisi and Kalebe (2015), Isomidinova and Singh (2017) suggested that the education system should introduce the financial literacy into their core of the curriculum. 


\section{Conclusion}

The conclusions of this study are Marital status does not affect the financial literacy. These findings suggest that single women tend to manage their finances while married women have different responsibilities in financial decision-making. The level of education affects the financial literacy. High school graduates, Diploma/Bachelor graduates are more significant in percentage, resulting in a positive influence on financial literacy especially in financial knowledge and behavior. Personal income affects the financial literacy. The higher the income women workers can be wiser in its financial management. Age does not affect the financial literacy. Financial socialization agent affects the financial literacy. The most influential social agents on financial information of women workers in the financial sector were the families of $78 \%$, then peers and media each at $72.4 \%$.

The primary recommendation in this study is that given the positive influence of education, income and financial socialization agent on financial literacy, the government can focus on educating the development and improvement of financial literacy for the society. It is believed to be a step forward in practicing financial planning from an early age to solve problems with financial management utilizing financial knowledge, financial attitude, and financial behavior.

\section{References}

Agarwalla, S. K., Barua, S. K., Jacob, J., \& Varma, J. R. (2013). Financial Literacy Among Working Young in Urban India. World Development. Vol. 67: 101-109. doi: https://doi. org/10.1016/j.worlddev.2014.10.004.

Agnew, S., \& Harrison, N. (2015). Financial Literacy and Student Attitudes to Debt: A Cross National Study Examining The Influence of Gender on Personal Finance Concepts. Journal of Retailing and Consumer Services. Vol. 25: 122-129. doi: 10.1016/J. JRETCONSER.2015.04.006.

Alwee, A. M. H., \& Salleh, P. M. (2015). A Comparison on Financial Literacy Between Welfare Recipients and Non-welfare Recipients in Brunei. International Journal of Social Economics. Vol. 42(7): 598-613. doi: https://doi.org/10.1108/IJSE-09- 2013-0210.

Amaliyah, R., \& Witiastuti, R. S. (2015). Analisis Faktor yang Mempengaruhi Tingkat Literasi Keuangan di Kalangan UMKM Kota Tegal (Analysis of Factors that Affect of Financial Literacy among the Small Medium Enterprises in Tegal City). Management Analysis Journal. Vol. 4(3): 252-257.

Andrew, V., \& Linawati, N. (2014). Hubungan Faktor Demografi dan Pengetahuan Keuangan Dengan Perilaku Keuangan Karyawan Swasta di Surabaya (The Relationship of Demographic Factors and Financial Knowledge With Private Employees Financial Behavior in Surabaya). FINESTA. Vol. 2(2): 35-39.

Ansong, A., \& Gyensare, M. A. (2012). Determinants of University Working-Students' Financial Literacy at the University of Cape Coast, Ghana. International Journal of Business and Management. Vol. 7(9): 126-133. doi: https://doi.org/10.5539/ijbm. v7n9p126. 
Brown, M., \& Graf, R. (2013). Financial Literacy and Retirement Planning in Switzerland. Numeracy. Vol. 6(2): 565-584. doi: https://doi.org/10.1017/S1474747211000485.

Daft, L. R. (2010). Era Baru Manajemen (New Era of Management). Jakarta: Salemba Empat. Garg, N., \& Singh, S. (2018). Financial Literacy Among Youth. International Journal of Social Economics. Vol. 45(1): 173-186. doi: https://doi.org/10.1108/IJSE-11-2016-0303.

Ghozali, I. (2014). Structural Equation Modeling: Metode Alternatif Dengan Partial Least Square (Structural Equation Modeling: Alternative Methode Use Partial Least Square). Semarang: BP Undip.

Hair, J. F., Hult, G. T. H., Ringle, C. M., \& Sarstedt, M. (2014). A Primer on Partial Least Squares Structural Equation Modeling (PLS-SEM). Los Angeles: Sage.

Henseler, J., Ringle, C. M., \& Sinkovics, R. R. (2009). The Use of Partial Least Squares Path Modeling in International Marketing. In Sinkovics, R. R., \& Ghauri, P. N. (Ed). New Challenges to International Marketing (Advances in International Marketing). Vol. 20: 277-320. United Kingdom: Emerald Group Publishing Limited.

Hilgert, M. A., Hogarth, J. M., \& Beverly, S. G. (2003). Household Financial Management: The Connection between Knowledge and Behavior. Federal Reserve Bulletin. Vol. 106: 309-322. doi: https://doi.org/10.1093/rfs/hhv072.

Hogarth, J. M., \& Hilgert, M. A. (2002). Financial Knowledge, Experience, and Learning Preferences: Preliminary Results from a New Survey on Financial Literacy', Proceedings of the American Council on Consumer Interests 2002 Annual Conference. Vol. 48: 1-7. Available at: http://www.consumerinterests.org/public/articles / $\% 5$ Cpublic $\% 5$ Carticles\%5CFinancialLiteracy-02.pdf.

Isomidinova, G., \& Singh, J. S. K. (2017). Determinantc of Financial Literacy: A Quantitative Study Among Young Students in Tashkent, Uzbekistan. Electronic Journal of Business and Management. Vol. 2 (1): 61-75.

Kumalaningrum, M. P. (2010). Pengaruh Gender Sebagai Pemoderasi Pada Hubungan Orientasi Pasar dan Kinerja Keuangan (The Influence of Gender as A moderating On the Relationship of Market Orientation and Financial Performance). Jurnal Riset Akuntansi dan Keuangan. Vol.6 (2): 99-112.

Lyons, A. C., Chang, Y., \& Scherpf, E. (2006). Translating Financial Education into Behavior Change for Low-income Populations. Journal of Financial Counseling and Planning. Vol. 17(2): 27-45. available at SSRN: https://ssrn.com/abstract=2232122.

Mahdzan, N. S., \& Tabiani, S. (2013). The Impact of Financial Literacy on Individual Saving: An Exploratory Study in The Malaysian Context. Transformations in Business and Economics. Vol. 12(1): 41-55.

Malhotra, N. K. (2005). Riset Pemasaran: Pendekatan Terapan Jilid 1. Ed 4 (Marketing Research: an Applied approach, Vol. 1. $4^{\text {nd }}$ edition). Jakarta: Gramedia Pustaka Utama.

Margaretha, F., \& Sari, S. M. A. Y. (2015). Faktor Penentu Tingkat Literasi Keuangan Para Pengguna Kartu Kredit di Indonesia (Determinants of Financial Literacy of The Credit Card Users in Indonesia). Jurnal Akuntansi dan Investasi. Vol. 16(2): 132-144. doi: https://doi.org/10.18196/JAI-2015.0038. 
Masche, J. G. (2010). Explanation of normative declines in parents' knowledge about their adolescent children. Journal of Adolescence. Vol. 33(2): 271-284. doi: https://doi.org/ 10.1016/J.adolescence.2009.08.002.

Mouna, A., \& Anis, J. (2017). Financial Literacy in Tunisia: Its Deteminants and Its Implications on Investment Behavior. Research in International Business and Finance. Vol. 39 (Part A): 568-577. doi: https://doi.org/10.1016/j.ribaf.2016.09.018.

Muat, S., Miftah, D., \& Wulandari, H. (2014). Analisis Tingkat Literasi Keuangan dan Dampaknya Terhadap Keputusan Pinjaman Pribadi (Analysis of Financial Literacy and its impact on Decision personal loans). Proceedings on Business Dynamics Toward Competitive Economic Region of ASEAN. Salatiga: FEB Universitas Kristen Satya Wacana, pp. 465-478.

Notoatmodjo, S. (2003). Pendidikan Dan Perilaku Kesehatan (Education And Health Behaviors). Jakarta: Rineka Cipta.

Organization for Economic Co-operation and Development [OECD]. (2016). International Survey of Adult Financial Literacy Competencies. Available at: http://www.oecd.org/ $\mathrm{daf} /$ fin/financial-education/OECD-INFE-International-Survey-of-Adult-FInancialLiteracy-Competencies.pdf.

Orton, L. (2007). Financial Literacy: Lesson From International Experience. CPRN Research Report. Vol. 9: 1-63

Potrich, A. C. G., Vieira, K. M., \& Kirch, G. (2015). Determinant of Financial Literact: Analysis of The Influence of Socioeconomic and Demographic Variables. Revista Contabilidade and Finances. Vol. 26 (69): 1060-1070. doi: https://doi.org/10.1590/1808-057x2015 01040.

Rasoaisi, L., \& Kalebe, K. M. (2015). Determinantc of Financial Literacy Among The National University of Lesotho Students. Asian Economic and Financial Review. Vol. 5(9): 1050-1060.

Remund, D. L. (2010). Financial Literacy Explicated: The Case for a Clearer Definition in an Increasingly Complex Economy. Journal of Consumer Affairs. Vol. 44(2): 276-295. doi: https://doi.org/10.1111/j.1745-6606.2010.01169.x.

Sarah, N. (2009). Financial Knowledge, Locus Of Control, Culturalvalues And Financial Behaviour Among New Vision Employees. (Unpublished Thesis). Kampala, Uganda: University Kampala.

Sardiana, A. (2016). The Impact of Literacy to Shariah Financial Service Preferences. Etikonomi. Vol. 15 (1): 43-62. doi: https://doi.org/10.15408/etk.v15i1.3115.

Scheresberg, C. D. B. (2013). Financial Literacy and Financial Behavior Among Young Adults: Evidence and Implications. Numeracy. Vol. 6(2): 1-21. doi: https:// doi. org/10.5038/1936-4660.6.2.5.

Sohn, S.-H., Joo, S. H., Grable, J. E., Lee, S., \& Kim, M. (2012). Adolescents' Financial Literacy: The Role of Financial Socialization Agents, Financial Experiences, and Money Attitudes in Shaping Financial Literacy Among South Korean Youth. Journal of Adolescence. Vol. 35(4): 969-980. doi: https://doi.org/10.1016/j.adolescence. 2012.02.002. 
Sundjaja, R., Intanie, V., \& Oriana, D. F. (2015) Perencanaan Keuangan untuk Memasuki Masa Pensiun Pada Karyawan di Institusi Pendidikan Swasta X di Bandung (Financial planning for Retirement On employees in X Private Education Institutions in Bandung). (Unpubished Thesis). Bandung, Indonesia: Universitas Katolik Parahyangan.

Vitt, L. A., Anderson, C., Kent, J., Lyter, D. M., Siegenthaler, J. K., \& Ward, J. (2000). Personal Finance and the Rush Competence Financial Literacy Education in the U.S. Working Paper. Virginia: Institute for Socio-Financial Studies.

Warsono. (2010). Prinsip-prinsip dan Praktik Keuangan Pribadi (The Principles and Practice of Personal Finance). Journal of Science. Vol. 13(2): 137-152.

Yidririm, M., Bayram, F., Oguz, A., \& Günay, G. (2017). Financial Literacy Level of Individuals and Its Relationship to Demographic Variables. Mediterranean Journal of Social Science. Vol. 8 (3): 19-26. 